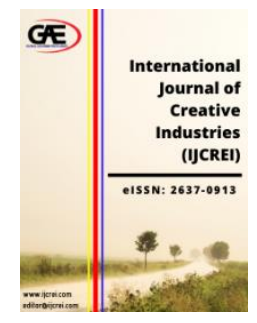

\author{
INTERNATIONAL JOURNAL OF \\ CREATIVE INDUSTRIES \\ (IJCREI) \\ WWW.ijcrei.com
}

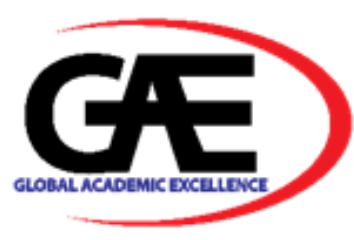

\title{
THE IMPACT OF MEDIA INFODEMICS ON COVID-19 OUTBREAK IN INTENSIFYING GLOBAL PANIC AMONG MALAYSIANS: A PERCEPTION-BASED ANALYSIS
}

\author{
Arlini Alias ${ }^{1 *}$ \\ 1 Centre for Bioethics and Humanities, International Medical University (IMU), Malaysia \\ Email: ArliniAlias@imu.edu.my \\ * Corresponding Author
}

\section{Article Info:}

\section{Article history:}

Received date: 11.01 .2021

Revised date: 18.01.2021

Accepted date: 05.02 .2021

Published date: 01.03.2021

\section{To cite this document:}

Alias, A. (2021). The Impact of Media Infodemics on Covid-19 Outbreak in Intensifying Global Panic Among Malaysians: A Perception-Based Analysis. International Journal of Creative Industries, 3 (6), 16-30.

DOI: $10.35631 /$ IJCREI.36002.

This work is licensed under $\underline{\mathrm{CC} B Y} 4.0$

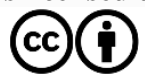

\section{Abstract:}

In Malaysia, the Restricted Movement Order's implementation has turned the media to become the main primary source of information for the people. As a result, numerous mendacious news about the Covid-19 outbreak began to appear on air. Such reports and claims made in response to the outbreak, which the World Health Organisation labelled as "infodemics," have been excessively proliferated on media (Thomas, 2020). Hence, the study explores the Malaysians' perceptions of the extent to which the Covid-19 outbreak infodemics produced by the local media amplify global panic in society. The study applies a qualitative research design, using a case-study analysis on perception to discover the Malaysians' awareness and views on the virus outbreak based on the media's information and how these contents elevate public reactions. Focus group interviews are conducted with 15 Malaysian citizens residing in five different states in Malaysia, namely Kuala Lumpur, Selangor, Negeri Sembilan, Johor, and Pulau Pinang. A set of 10 open-ended questions are probed to participants during the interviews. Data are analysed following a deductive approach and clustered according to the research questions. The following five-step framework is applied: data familiarisation, thematic analysis framework, coding, plotting, and interpretation. The validity of data is achieved through inter-rater reliability. Four themes, namely media preferences and mainly sought information, awareness of the fake news spread on media, news reliability check, and reaction-based impact in response to the infodemics were established. The majority of the participants favoured official news broadcasts for updates on the outbreak. A few of them reported consuming infodemics that were conveyed by social media platforms. Participants indicated being well-informed on the spread of fake news on media, and $53 \%$ reported difficulties in verifying the information they received due to excessive coverage by media. Finally, $60 \%$ of the participants reported 
Volume 3 Issue 6 (March 2021) PP. 16-30 DOI: 10.35631/IJCREI.36002

a significant influence of the infodemics they consumed towards their perceptions and reactions.

Keywords:

Media Infodemics, Covid-19 Outbreak, Intensification Of Global Panic, Perception-Based Analysis

\section{Introduction}

The Coronavirus 2019 (COVID-19) infection has become a global pandemic which recorded over 5.25 million cases and 339,000 deaths worldwide ("Covid-19," 2020), and the number is still accumulating. The first case in Malaysia was confirmed by the Malaysian Ministry of Health in January 2020, involving three Chinese nationals entering Malaysia from Singapore ("Kronologi Covid-19," 2020). Soon after, the virus continues to extend throughout the entire nation. The first death in Malaysia was recorded in early March 2020 (Duddu, 2020). On March 18, 2020, the Malaysian government announced a two-week Restricted Movement Order (RMO) to curb the spread of the virus within the country, which later was extended further due to the increased number of infected cases.

The rapid spread of the virus has instigated excessive demand for information from society (Sokolov, 2020). In Malaysia, due to RMO's implementation, the media has turned out to be the primary source of information for the people. Studies reveal that during the times of crisis, media use in discovering information mainly on protection, latest updates, or even damage reports of the crisis is significant (Seo, 2019). Hughes and Palen (2012, cited in Seo, 2019) claim that media, especially social media, has the ability to speed up the dissemination of information during the occurrence of the crisis. As a result, numerous mendacious news about the disease began to appear on the air. This fuel of claims on the media, of which the reliability was not attested, has initiated great fear among the people. The extent of this fake news and claims made with regards to the pandemic is labelled as "an infodemic" by the WHO (Thomas, 2020). In expressing his testament to the influence of media in disseminating fallacious information about the disease, hence, shaping fear and panic among the people, the WHO Director asserts that "we're not just fighting an epidemic, we're fighting an infodemic." (In Sokolov, 2020). The term "infodemic" is a combination of the word "information" and "epidemic," which is coined by David Rothkopf, a scientist and a journalist at the Washington Post press in 2003 while reporting the outbreak of equally fear-provoking related epidemic; SARS (Merriam-Webster, n.d.). Rothkopf (2003) explains that infodemic refers to "a few facts, mixed with fear, speculation, and rumour, amplified and relayed swiftly worldwide by modern information technologies, have affected national and international economies, politics and even security in ways that are utterly disproportionate with the root realities." (The Washington Post, 2003. In Merriam-Webster, n.d.).

Hence, this paper explores the Malaysians' perceptions of how Covid-19 Outbreak infodemics produced by the local media amplify global panic in society. Using a qualitative research design, the study aims to discover the people's understanding and opinion on the disease outbreak based on the information conveyed by the media and how these elevate public reactions. The study aims to answer the following questions: 
1. What is media information mostly sought by Malaysians about the COVID-19 outbreak?

2. How do Malaysians construe media reports about the COVID-19 outbreak in Malaysia?

3. To what extent do Malaysians aware of the spread of fake news on the Covid-19 Outbreak?

4. To what extent do media infodemics influence Malaysians' public reaction towards the current state of the COVID-19 outbreak?

\section{Literature Review}

\section{Risk Perception and Social Amplification of Risk Theory}

Contemporary cognitive psychology acclaims that there are two systems in which people use to comprehend threat or risk: analytical and experiential (Slovic et al., 2004). Analysing threat or risk using an analytical method is through the utilisation of sets of normative rules, namely risk valuation, probability assessment, and formal logic, in which specific attentive measures are performed. The experiential method, on the other hand, is based on intuition, whereby a person receives minimum access to what is called "conscious awareness" (Slovic et al., 2004). Slovic et al. (2004) state that this method is known to be one of the most common and prompted ways people respond to threats or risks. It is stated that humans tend to rely on the event's image representation and its associative characteristics, which they then link to their individual experience that usually accompanies by particular sentiments and feelings (Slovic et al., 2004). This system signifies a sense to the degree of the threat or risk since all threats/risks are regarded as naturally "subjective" (Delgado, 2014). According to Delgado (2014), people apply several psychosomatic devices when evaluating risks, one of which is the "mental shortcuts" (heuristics and risk imageries), which are found to be persistently modified by media reports. Wanchinger et al. (2013. In Delgado, 2014) indicate that five dominant factors influence one's perception and/or judgment of the severity of threats/risks where the reaction is formed: "risk factors, informational factors, personal factors, direct experience, and trust." The risk factor refers to the probability and the extent of the threat/risk. The informational element is most crucial during the nonappearance of direct experience, whereby the dependence upon the information received from media sources is paramount. Another factor that helps form risk perception is the trust factor - the high level of confidence one has in the authorities' actions and efforts to protect the nation against the threat and/or risk (Wanchinger et al., 2013 In Delgado, 2014). This theory helps the researcher comprehend the driven factors that influence or build one's construct of perception regarding the Covid-19 outbreak being the most ominous threat currently affecting the nation.

Another theory that helps the researcher to gain a deeper understanding of how to measure risk perception is the Social Amplification of Risk Theory by Kaperson et al. (1988; 2010). This theory is based on the notion that hazardous occurrences correlate "with psychological, social, institutional, and cultural processes in ways that may amplify or attenuate public responses to the risk or risk event." (Kaperson et al., 1988). According to Kaperson et al. (1988), there are two phases in which intensification occurs: during the broadcasting of the threat as well as in the "response mechanisms" of the public. Amplification station processes risk signals through the assessment of the following constituents: the transcender(s) of the risk assessment, the extent of news coverage, physical significances, the personal layperson views, the public reactions, as well as the socioeconomic and political impacts (Renn et al., 1992). The higher 
Volume 3 Issue 6 (March 2021) PP. 16-30 DOI: 10.35631/IJCREI.36002

the threat is ruled on these factors, the greater its perceived risks, "and the more people want to see its current risks reduced and regulated." (Slovic, 1987)

The more intensified the risk becomes, the greater the behavioural responses to be activated, which lead to what Kaperson et al. (1988) termed as "secondary impacts." The amplification stations are demonstrated in the below figure:

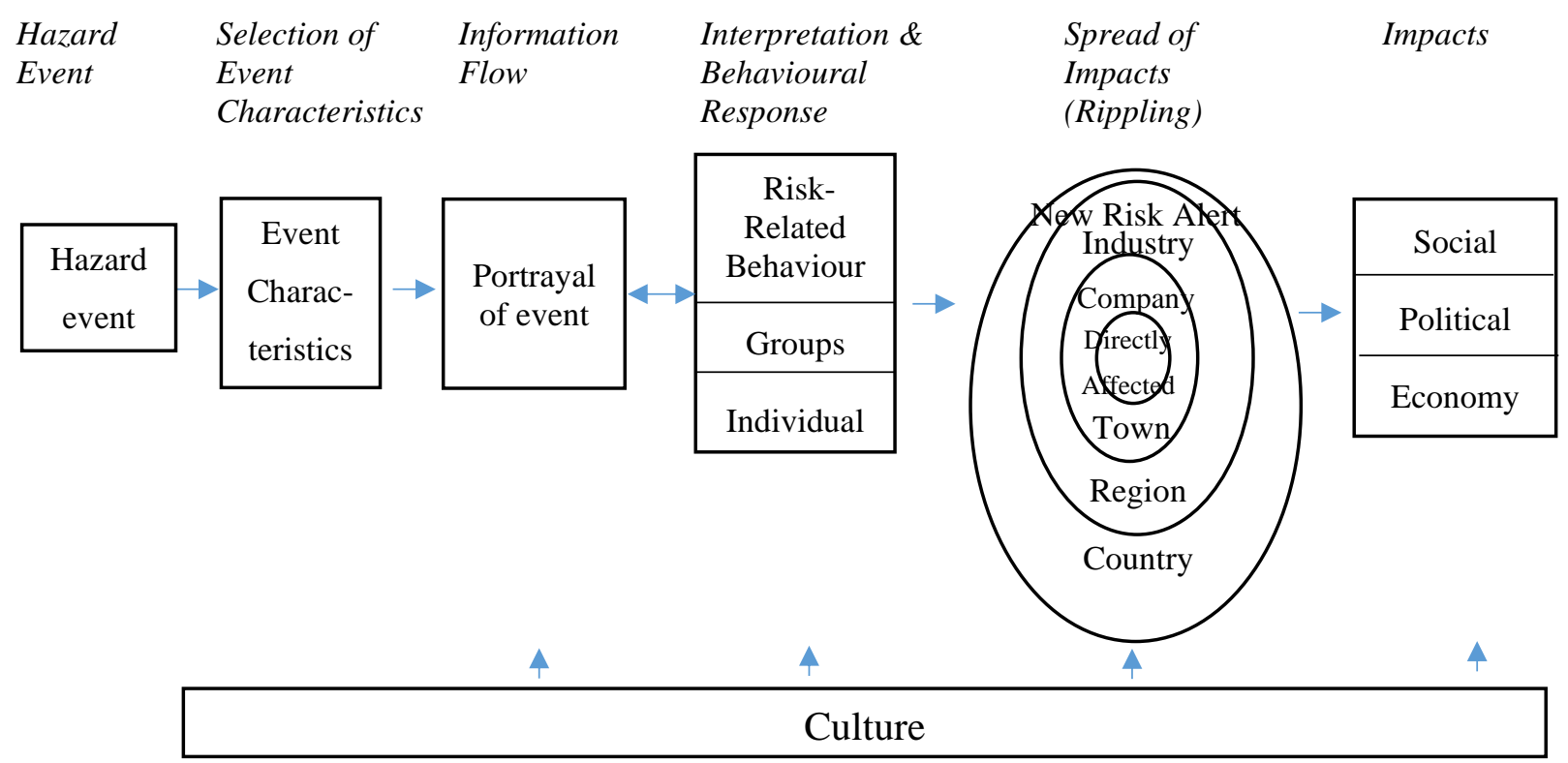

Figure 1: Social Amplification of Risk

Source: Kaperson et al., 1988: Rent et al., 1992, p.141

A study conducted by Renn et al. (1992) integrated the analysis of technical assessment and the social experience of risk in the social amplification of risk framework. Based on their findings, both perceptions and social reactions have a significant association with risk exposure than the amount of the risk-related information received. According to Renn et al. (1992), an individual's selection of significant information plays a vital role in the process of decoding and processing risk-related information. The constituents of the decoded message that are conflicting with the beliefs or the recipients' values are either mitigated or disregarded. Instead, when the decoded message is in accordant with the recipients' beliefs and values, "the signals are intensified." (Renn et al., 1992). Consequently, an individual's act becomes part of the larger social units that "co-determine the dynamics and social processing of risk." (Renn et a., 1992).

\section{Methodology}

The researcher applies a qualitative research design, in which a case-study analysis of perception is performed to analyse data collected from focus group interviews. A set of ten (10) open-ended questions were probed to participants during the focus group interviews. A total of fifteen (15) Malaysian citizens residing at five different states in Malaysia, namely Kuala Lumpur, Selangor, Negeri Sembilan, Johor, and Pulau Pinang, are included in the study. The first four earlier-mentioned states are affected the most by the pandemic among other states in Malaysia (Statista Research Department, 2020). The selection of these five states is also meant to examine if there are any differences in how people from different states react to the infodemics they receive from the media. From a total of fifteen participants, ten (10) are female, 
Volume 3 Issue 6 (March 2021) PP. 16-30 DOI: 10.35631/IJCREI.36002

and five (5) are male, and the age range of the participants is from 25 to 70 years. A total of seven focus group interview sessions with the participants were conducted from May 2020 to July 2020, using Richard A. Krueger (2002) Focus Group Interviewing protocol. Data analysis of the study was undertaken systematically following the five-step framework below:

Step 1: Data structuring and familiarisation - Transcription, translation, and reading Step 2: Identification of a thematic framework - An explanatory structure is applied in which the research questions guide the coding plan.

Step 3: Data Coding - Sorting data into the selected framework

Step 4: Plotting/Data Linking - Arrangement of the responses into categories and identification of the recurrent themes

Step 5: Interpretation - Examination of patterns in the data, identification of clusters (causality and related themes), construction of a sequence of events, data localisation to answer research questions

In ensuring the credibility and validity of the results, an analyst triangulation method of crosschecking data is applied; whereby two raters were appointed to develop inter-rater reliability checks on the consistency of the findings. The focus group interviews are conducted in eight (8) separate sessions, in which the participants were then pooled into group characterisation following their residing states. These participants are also selected based on their active media interaction and engagement, including social media. The researcher uses the social Amplification of Risk and Risk Perception theories as to the main framework of analysis in this study, which serves as a platform for the researcher to explore participants' construct systems related to Covid-19 infodemics on the media. Hence, this will also enable the researcher to reveal the formation of their constructs, which later form their reaction or behaviour.

\section{Findings and Discussions}

\section{Media Preferences and Mainly Sought Information of Covid-19 Outbreak}

The participants were asked to indicate which media sources they prefer for the latest updates on the Covid-19 outbreak and the reasons for their preference(s). The analysis is as below:

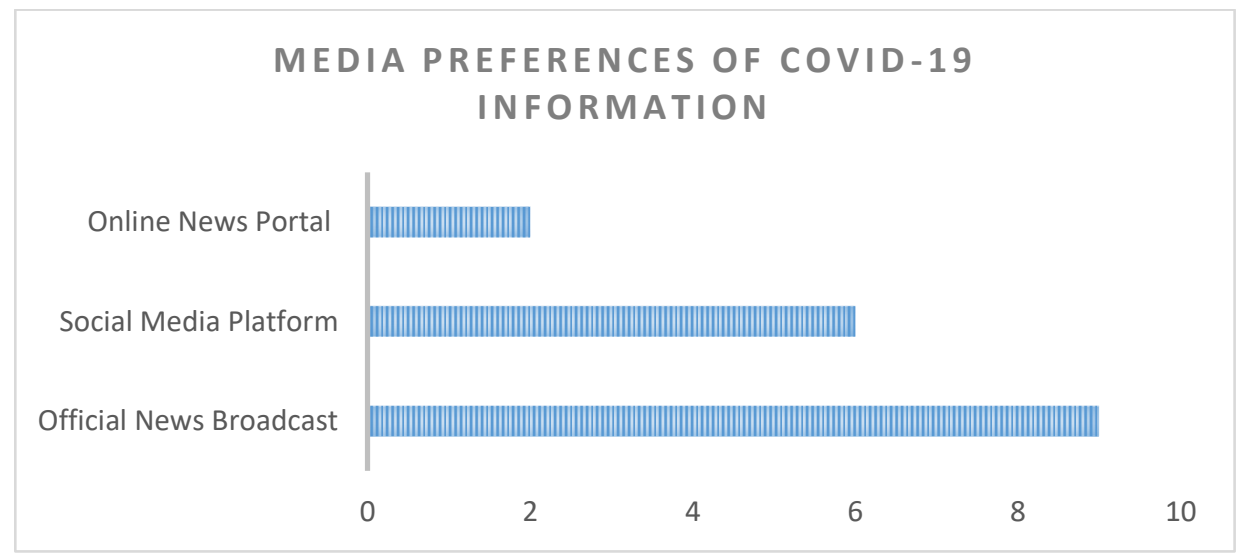

Figure 2: Media Preferences of Covid-19 Information 
Volume 3 Issue 6 (March 2021) PP. 16-30 DOI: 10.35631/IJCREI.36002

Based on the analysis, official news broadcast, social media platform, and online news portal are the three leading mainstream media that the participants mainly refer to in attaining the Covid-19. The majority (nine) of the participants indicated their preferences over official newscasts and press conferences for the latest updates and information on the Covid-19 outbreak. Six of a total of nine participants who preferred the official newscasts and press conferences were from the range of ages between 50 to 70 years. This preference is due to the reason of news accuracy. Additionally, six participants shared that they also turn to social media platforms for the Covid-19 updates, mainly for two reasons: information retrieval is faster, and more detailed information that the official news would not highlight can be obtained. Besides, two participants also stated their preferences for using the online news portal as the primary medium for Covid-19 updates because of their work schedules. Hence, it is more effective for them to refer to the online news portal. Next, the participants were asked about the sorts of information they mostly search on media regarding the Covid-19 outbreak. Twelve of the fifteen participants reflected that they are more attentive to the daily reports of the Covid19 new confirmed and recovered cases, as well as its fatality rate. Also, two participants reported the information they mainly sought on media about the pandemic is on its preventive measures and the updates of which states in the country that is mostly affected. Besides, one participant identified that he mainly sought information through media is on the latest news of vaccine development for the Covid-19 virus and the effectiveness of the government and other countries in the world.

\section{Awareness of the Covid-19 Outbreak Fake News Spread on Media}

Participants were also asked about their opinion about media coverage of the Covid-19 outbreak and their awareness of the fake news spread on media with regards to the outbreak. Eleven participants agreed that most media in Malaysia, especially the broadcasting agencies, have excellently played their role in disseminating sufficiently up-to-date information and relevant news of the global pandemic Covid-19 to the public, preventing global panic endurance from taking place in the society. Below are some of the feedback gathered from the participants:

...the pro is the main official media is trying to make sure enough information is supplied to the people... like when the official announcement is made twice a day... (P2-PP)

On average, media in Malaysia is still in control of spreading the news about the virus... (P3$\mathrm{PP})$

Media in Malaysia provide sharp reports and transparent news...they showcase a direct interview with the authority... (P4-JHR)

Those people are panic because they only listened to the information partially, not fully...Media is giving us a clear picture of the outbreak... (P5-JHR)

Informative and up-to-date... And provide sufficient information without detailing things as not everybody knows the details of the outbreak, but sufficient for common people to understand about the outbreak... (P7-NS)

Good coverage... focus on disseminating information from accurate data... (P8-NS)

Good and clear... they mainly highlight important information ... (P10-SLGR) 
Volume 3 Issue 6 (March 2021) PP. 16-30 DOI: 10.35631/IJCREI.36002

They are doing a good job in terms of providing people good info to the public... that's why we don't see our people that panic... (P11-SLGR)

Malaysian newsagents are doing a great job in disseminating information about the outbreak... (P14-KL)

Four participants highlighted the occurrences of a discrepancy, spread of exaggerated information, and news overload of the Covid-19 outbreak, that triggered the incitation of panic among some people in the community, as well as distracting the community from other issues that are no less important:

...the con is some of the information are just briefed... that made people become panic... more details are required... (P2-PP)

... but, a few media tend to politicise on the issue... (P10-SLGR)

... some media provide exaggeration of information, that's why people start to panic... (P12SLGR)

Everywhere on media, you hear only about the outbreak... until other important news is overshadowed... (P13-KL)

The next question is examining the role of media in the construction of public belief regarding the spread of the outbreak. Participants were asked whether they believe everything they read on the media with regards to the Covid-19 outbreak. Five participants reported that they consider mostly everything they read on the media. One of the participants further explained that she considers the infodemics spread on the media due to her understanding that there is always a requirement for the official mainstream media to appear neutral in their informationsharing and the need to avoid the production of public panic

....yes, I believe, sometimes the official media tend to hide the truth, not to create panic among people... (P4-JHR)

Another participant highlighted that she has difficulties in determining the credibility of the news she read on media, hence, causing her to believe almost all information she received:

Sometimes, I do face difficulties to differentiate which news is true and which is not. So, I ended up believe almost everything I read... (P3-PP)

On the other hand, six participants conveyed that their consumption of the news depends on the medium of media where the information is channeled. From the analysis, official news broadcasts are mostly relied on by the participants. Besides, another participant reported that her consumption of the information regarding the outbreak is reliant on the types of information she received, in which she only consumes health-related information.

Depends on the type - if health-related, I mostly believe... if politics related - not so much ... because they could be the propaganda... (P10-SLGR) 
Besides, one participant raised the importance of considering only factual information received on media and the need for cross-checking.

...Just believe in facts...It's better to fact-check the information we receive, as we cannot rely on one source only... Must always do cross-check... (P6-JHR)

The following question is determining participant's self-awareness on the proliferation of Covid-19 infodemics on media. All the fifteen participants reported that they are aware of the far-reaching spread of Covid-19 infodemics across all media. The two main infodemics they encountered include the made-up preventive measures and conspiracy theories and media propaganda on the occurrence of the outbreak.

Yes, (because) nowadays, the related ministries react immediately by publishing their official statements regarding fake news. By then, we can get quick info whether it is true or fake news... (P6-JHR)

Yes, but I'm not affected by the propaganda spread on media because I rely only on news given by the DG (Malaysian Director-General of Health) ... (P7-NS)

Yes, like eating garlic and ginger could prevent you from getting the Covid-19 virus...it's so untrue... No evidence... (P8-NS)

Yes, very much, especially the International media, such as rumours related to China spreading the virus and so on... (P10-SLGR)

I'm aware, they tend to misuse and politise the information to attract attention from the public. For example, the issue of human right in the beginning when the government started the implementation of the MCO and the news agencies tried to create propaganda that the country is safe from the pandemic... (P11-SLGR)

... the fake news seems to overshadow the real stories... Many are creating assumptions from what they hear or read... Old people or those who can't make good judgment will be most affected... (P12-SLGR)

According to one of the participants, based on her investigation, some of the alleged infodemics of conspiracies with regards to the Covid-19 outbreak spread mainly on social media appeared to correspond to the reliable study papers that she had read, which led her to consider most of the news:

.... some of the conspiracy \& propaganda spread mostly on social media are tally with the studies that I read, especially on the use of virus transmission as a tactical strategy of war... Same like the trade war which is happening between China and the U.S...Usually this kind of news, you don't get from the official media... (P4-JHR)

\section{News Reliability Check}

Additionally, participants have also been queried on their accountability of self-checking the news accuracy. Eight of the fifteen participants acknowledged the difficulties of assessing the Covid-19 outbreak news' validity due to excessive media coverage and reported that they consume information mainly from the official news broadcast/portal. Below are some of the participants' responses: 
Volume 3 Issue 6 (March 2021) PP. 16-30 DOI: 10.35631/IJCREI.36002

Not so... Very hard to check because there are so many news about the virus on media... So, I will see if I can adopt, I will... If not, I just take information from the official news... (P1-PP)

I only believe news from the announcement made in official press conferences... (P2-PP)

Information from the press conferences... That is our responsibility to find the validity of the information we receive from media... (P5-JHR)

I only refer to official news... I don't dare to read from other than the official news, because too many exaggerated information that makes me scared... (P8-NS)

...same... Don't believe news from other than the official news... (P9-NS)

I only refer to the mainstream media, MKN and MOH official website... (P11-SLGR)

... Only take information from the KKM page... (P14-KL)

Seven participants indicated that they also consume information other than the ones conveyed by the official newscasts, such as those published on social media, but sought news accuracy. From the feedback, two main methods applied by the participants in assessing the credibility of the news include evaluating sources and fact-checking:

I read more of news spread on social media... sometimes the news is reliable as when I checked with several sources... Most of the time...they are just propagandas. (P3-PP)

I am also one of the people who read on the Covid-19 conspiracies... the conspiracy theory and propaganda spread on media are quite tally with the evidences I found... I found some evidences from the claim made from the conspiracy theory spread... When I check the reliability - my evidences from the research studies and investigation suit the news propagated on media regarding the conspiracy of the outbreak... (P4-JHR)

I always check the source of the information first before I believe or spread... through the official MOH page... (P6-JHR)

I will cross-check with the ones announced by the DG Hisham Mohd Noor on the official press conferences... (P7-NS)

I read further on recent studies/articles on the flow and agendas of the news... (P10-SLGR)

.... always check the additional information I got from social media with the ones on news... (P12LGR)

Double-checking through various media outlets, such as TV, internet \& newspapers... (P15-KL)

\section{Reaction-based Impact due to the Covid-19 Outbreak Infodemic News}

The final inquiry is to assess the consequence of the proliferated Covid-19 Outbreak infodemics spread on media to the participants and the people in their residing area based on their observation. Four questions were probed to the participants under this theme. First, the participants have asked to identify which news or information they read on media that mostly trigger(s) their reaction(s) with regards to the outbreak. From the feedback, eleven Copyright (C) GLOBAL ACADEMIC EXCELLENCE (M) SDN BHD - All rights reserved 
participants responded they were, to a certain degree, prompted by some of the news they read on media with regards to the spread of the Covid-19 virus and reacted upon the information they received. Six participants reported that the main infodemic that activated their reactions is the shortage in supplies of essential items:

The spread of the virus as well as the country's current state... I was panicked when the facemask and hand sanitizer were out-of-stock in my area ... (P4-JHR)

... the most triggered news was that mask and hand sanitizer were out of supply and sold out everywhere... So I stocked up both for my family... (P6-JHR)

Earlier, after lockdown, when the MCO is announced, the government also announced that state cross-border travel is no longer allowed... I was stuck in my village... so, I become depressed and panicked... Secondly is during the second wave... too much news on how the virus is spread... every time I went out, even just to throw trash in the trash bin, I had a panic attack because I am scared that I might get the virus... I did panic buying, mostly my kid's necessities, like tissues and pampers... due to news I heard that my area is going to have PKPD and there were short of supplies for these two items... (P10-SLGR)

I read that many people were keeping food stock... so, I end-up did the panic shopping too... (P12-SLGR)

I read somewhere that China led the virus out... I become suspicious of why would people do that - harm their own people and country. I do panic shopping... (P13-KL)

The panic shopping... (P14-KL)

Another infodemic that prompted the participants' responses is the significance of increasing the level of personal hygiene and maintain a clean environment:

... news about how fast the virus spread and reasons for its spread... I didn't dare to even step out from the house as they say the virus easily affects the elderly like me... (P1-PP)

How the virus is spread and the importance of having good hygiene... I tried to observe cleanliness at all times... (P2-PP)

How it can spread and how to prevent from getting it... I got paranoid to go out ... (P3-PP)

... not so much ... One that is on cleanliness... made me sanitised my whole house... (P7-NS)

The number of death every day... I'm concerned with how severe it can be... I do ensure a hygienic environment in my house... (P15-KL)

Four of the participants reported that the news of the Covid-19 spread they read on media does not prompt their panic reactions. The reason being is that they are confident with the government's capability to control the spread of the virus as well as the accuracy of the information presented by the mainstream media:

... no, because I'm following the news on a daily basis... those news are giving us factual information and guide us on what to do and so on ... So, I don't get panic... (P5-JHR) 
Volume 3 Issue 6 (March 2021) PP. 16-30 DOI: 10.35631/IJCREI.36002

... On how the virus is spread... But, I'm not panic... The government is doing its best... (P8-NS)

The number of people cured and died... I'm not triggered by the rumours on media because I have high confidence in the government's ability to control the spread of the virus... (P9-NS)

The information from the mainstream media and the advice from the $\mathrm{MOH}$ page changed my behaviour because for me only news from these sources are reliable... (P11-SLGR)

Next, the participants were asked to state their opinions based on their observation on the extent the Covid-19 infodemics influence the people in their neighbourhood area and the public in general. Eight participants attested that there had been a nonappearance of intensification of reaction among the people in their neighbourhood areas based on their observation. Of the eight participants, all the three participants from Negeri Sembilan and two from Pulau Pinang reported that the people in their areas reflect a composed reaction with regards to the spread of the outbreak infodemics. Below are some of the feedback:

... A few only who went panic... Most of the people in my area are just calm. Perhaps because my area is listed as a green area... (P2-PP)

The people in my area is not panic... We do have enough food supply and so on... a few did panic buying... But I do not have any problem in my area... (P3-PP)

In my area, not so much... I don't see anyone panic... No issue with the shortage of food supply or things like that... Everyone is just following the government's order accordingly... (P5-JHR)

People in my area are not really influenced by the infodemics... all are relaxed and calm... (P7NS)

My area is just calm... Everyone stays at home and buy things only needed... No panic shopping or whatsoever... (P8-NS)

I guess it is not... as I see some people still bring small children to the mall... (P15-KL)

On the other hand, seven participants, of which two participants, each from Johor, Selangor, and Kuala Lumpur, indicated the panic reaction occurrences among the people in their residing areas. From their observation, the panic reaction involved the intensification of panic buying among the people.

Some people don 't comply with the SOPs and instructions... like when the government announced the PKP... some people still go to the market and not practicing social distancing... Some were panicked and bought a lot of groceries because they read on news of the short of supply... (P1PP)

In my neighbourhood, there is a WhatsApp group where people shared information and most of them believe it... Like, when people spread that there is a lack of food supply... so, people in my area ended up committing panic buying ... Also, due to the press conference... when the ministry mentioned the need to retain our food security... making people believe that it is really not enough food supply... (P4-JHR) 
Volume 3 Issue 6 (March 2021) PP. 16-30 DOI: 10.35631/IJCREI.36002

... Mask shortage ... people who don't wear masks were looked weird by others... Even the shops also don't allow those who don't wear a mask to enter their shops... (P6-JHR)

In the beginning, people in my neighbourhood do show panic reactions to a certain extent... (P10-SLGR)

Some people at my place do panic... and shops were almost emptied... (P12-SLGR)

... Same... I do see panic reaction in my neighbourhood... people were starting to stock-up facemasks, sanitisers and gardenia bread which later I saw a lot on the garbage bin because you know... that the bread can only last for a few days... (P13-KL)

Some were panic during the early stage of the outbreak as they were so many information being spread and some were not verified at that time... so, people get panic... (P14-KL)

Following that, with regards to the extent the Covid-19 infodemics influence the public reaction in Malaysia, ten participants reported that they observe the occurrence of panic reactions among Malaysians, especially during the early stage of the country's outbreak. It is mainly due to the massive news coverage of the Covid-19 spread, some of which were not verified.

In the beginning, many people go panic when they read a lot of information on media, like on WhatsApp, Facebook... (P1-PP)

Everywhere, people started to buy a lot of masks... and the price of the masks hiked up because there were announcements on the news that we all need to wear mask... To go to public places, suddenly we are asked to wear masks... (P2-PP)

Yes, I do observe people from other states went panic, especially in the beginning where there were a lot of information spread on media that could not be confirmed... (P3-PP)

A lot of information and propaganda I read on media triggered my panic reaction... I was freaking out and did the panic buying... I feel that some media seems to be covering something like the truth about the spread of the virus... In the official website, of course, they need to ensure for people to keep calm... so, I cannot rely 100\% on official media as that is their nature, to show that everything is under control, so people don't freak out... So, I read from other sources, the propaganda... (P4-JHR)

The price of mask and hand-sanitizer hikes up so much because people were panic that both are sold out everywhere... (P6-JHR)

I'm worried to go out of the house... Even to go out to throw rubbish in front of the house, also makes me scared... because I'm old and due to the decline of immunisation in old people... I become phobia... I don't want others to come to my house as I have 80 years old mom staying with me... So I become extra cautious... (P7-NS)

Most people comply with the instructions because they are scared... (P10-SLGR)

... They are quite concerned... whatever media informed, people, react for the security of the family and self... (P11-SLGR) 
Volume 3 Issue 6 (March 2021) PP. 16-30 DOI: 10.35631/IJCREI.36002

There were panic reactions among Malaysians... Perhaps, because the sellers were starting to over-charge some of the essentials items, and all the speculations spread on media... those are the things that make people become panic... (P13-KL)

People are influenced by the infodemics they read on media... Like, suddenly the price of the mask hikes up and so on... (P14-KL)

However, the remaining five participants observed that most people in Malaysia remain composed during the spread of the Covid-19 outbreak in the country compared to people from other countries in the world.

... So far, Malaysians are reacting well to the outbreak - not too bad... (P5-JHR)

I see people in other countries reacted worse than us here in Malaysia... so, I think our people are much more calm and able to follow the government's order accordingly... That's why the situation in our country is still under-control... (P8-NS)

Compared to other countries, it is clear that our government is doing an excellent job in handling the spread of information about the virus, as well as controlling the spread of the virus itself... (P9-NS)

Not as bad as people in other countries... Although a few were panicked, most are able to follow the authority's instructions accordingly and react calm... (P12-SLGR)

I guess it is not effective, as People still bring small children to the mall... (P15-KL)

Finally, participants were asked to measure their reactions and behaviours in response to the Covid-19 outbreak that are influenced by the information they consume from the media based on a five-point scale (nine-ten being mostly influenced). The analysis of the data is presented in the table below:

Table 1: Impact of Covid-19 Media Infodemics in Intensifying Panic Reactions

\begin{tabular}{|c|l|c|c|}
\hline Scale & Indication & Frequency (n) & Percentage \% \\
\hline $0-2$ & Insignificant & 1 & 6.7 \\
\hline $3-4$ & Low & 0 & 0.0 \\
\hline $5-6$ & Moderate & 5 & 33.3 \\
\hline $7-8$ & High & 7 & 46.7 \\
\hline $9-10$ & Severe & 2 & 13.3 \\
\hline
\end{tabular}

Based on the rate of recurrence presented in the above table, it can be observed that the majority of the participants $(60 \%)$ rated significant behavioural responses with regards to the Covid-19 outbreak based on the infodemics they consumed through media, which is between high $(46.7 \%)$ to severe $(13.3 \%)$. On the other hand, $33.3 \%$ of the participants indicated that they are moderately affected in their behaviours and reactions by the news and information they obtained through media. Only one participant reported that the infodemics spread on media with regards to the Covid-19 outbreak. 
Volume 3 Issue 6 (March 2021) PP. 16-30 DOI: 10.35631/IJCREI.36002

Table 2: Distribution of Intensification of Panic Reactions based on Covid-19 Media Infodemics According to States

\begin{tabular}{|c|c|c|c|c|c|}
\hline State & $\begin{array}{c}\text { Insignificant } \\
(\mathrm{n})\end{array}$ & $\begin{array}{c}\text { Low } \\
(\mathrm{n})\end{array}$ & $\begin{array}{c}\text { Moderate } \\
(\mathrm{n})\end{array}$ & High (n) & $\begin{array}{c}\text { Severe } \\
(\mathrm{n})\end{array}$ \\
\hline Pulau Pinang & - & - & 1 & 2 & - \\
\hline Johor & - & - & 1 & 1 & 1 \\
\hline Negeri Sembilan & - & - & - & 3 & - \\
\hline Selangor & - & - & 1 & 1 & 1 \\
\hline Kuala Lumpur & 1 & - & 1 & 1 & - \\
\hline
\end{tabular}

The data analysis of participants' overall observation of their reactions can also be distributed according to states. It is revealed that the majority of participants from Pulau Pinang, Johor, Negeri Sembilan, and Selangor reported a significant correspondence to the intensification of panic reactions with the Covid-19 outbreak infodemics spread by media, in which the rate ranged from high to severe. However, Kuala Lumpur participants reported that they are not significantly affected by the Covid-19 outbreak infodemics spread by media.

\section{Conclusions}

The impact of the Covid-19 infodemics spread on media in intensifying panic reactions among Malaysians. Albeit on a small scale, the study reveals that the spread of infodemics on media regarding the outbreak directly influences the public's perception of the epidemic's current state, affecting their reactions and behaviours in coping with the virus outbreak. The study also discloses that participants appear to seek personalised risk information infrequently when it comes to crisis and emergency risk communication. In this process, an individual's risk assessment results are tailored to an individual's preference intended use. They also appear to favour factual (evidence-based) information such as the statistical report of new cases and death from official media broadcasts. In addition, the study discloses that $60 \%$ of the participants reflected a significant impact of the Covid-19 infodemics spread towards their perceptions and reactions. Finally, the results demonstrate an insignificant variance in the impact of covid-19 infodemics towards the public responses with the risk occurrences in that particular state(s). Hence, it could imply that the infodemics spread on media have shaped the public's perceptions and understanding about the outbreak of the Covid-19 virus, which initiate their panic reactions.

\section{References}

Ahmad A.R., \& Murad H.R. (2020). The Impact of Social Media on Panic During the COVID19 Pandemic in Iraqi Kurdistan: Online Questionnaire Study. Journal of Medical Internet Research (JMIR), 22(5). Retrieved from https://www.jmir.org/2020/5/e19556

Bastani, P., \& Bahrami, M. A. (2020). COVID-19 Related Misinformation on Social Media: A Qualitative Study from Iran. Journal of medical Internet research, 10.2196/18932. Advance online publication. Retrieved from https://doi.org/10.2196/18932

COVID-19: Lebih 5.25 juta kes, 339,000 kematian seluruh dunia (2020, May 24). Berita Harian Online. Retrieved from https://www.bharian.com.my/dunia/eropah/2020/05/69 2394/covid-19-lebih-525-juta-kes-339000-kematian-seluruh-dunia 


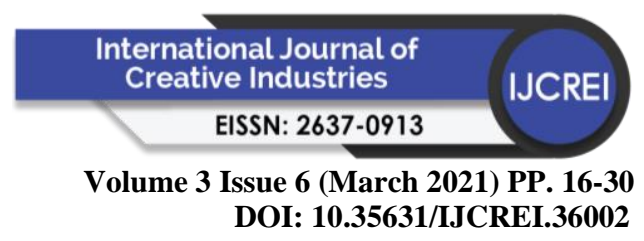

Delgado, A. (2014). Risk Perception, Disease Reporting, and Cooperation with Emergency Response: Foundations for Effective Risk Communication. slideserve.com. Retrieved from https://www.slideserve.com/owen-ross/risk-perception-disease-reporting-andcooperation-with-emergency-response

Duddu, P. (2020). Coronavirus in Malaysia: COVID-19 outbreak, measures and impact. Pharmaceutical Technology. Retrieved from https://www.pharmaceuticaltechnology.com/features/coronavirus-affected-countries-malaysia-covid-19-outbreakmeasures-tourism-economy-impact/

Ferdinand-James, D.S. (2015). Are "perceptions" survey research or case study or both?. Research Gate Publication. Retrieved from https://www.researchgate.net/post/Are_perception

s_survey_research_or_case_study_or_both

Infodemic. (n.d.). In Merriam-Webster.com dictionary. Retrieved from https://www.merriamwebster.com/words-at-play/words-were-watching-infodemic-meaning

Kaperson, et al. (1988). The Social Amplification of Risk: A Conceptual Framework. Society for Risk Analysis, 8(2), 177-187. Retrieved from https://onlinelibrary.wiley.com/doi/pdf /10.1111/j.1539-6924.1988.tb01168.x

Kronologi COVID-19 di Malaysia. (2020, March 17). Berita Harian Online. Retrieved from https://www.bharian.com.my/berita/nasional/2020/03/666122/kronologi-covid-19-dimalaysia

Nawrat, A. (2020, February 27). Covid-19 outbreak: how misinformation could fuel global panic. Pharmaceutical Technology. Retrieved from https://www.pharmaceuticaltechnology.com/features/covid-19-outbreak-how-misinformation-could-spark-globalpanic/

Renn, et al. (1992). The Social Amplification of Risk: Theoretical Foundations and Empirical Applications. Journal of Social Issues, 48(4), 137-160. The Society for the Psychological Study of Social Issue. Retrieved from https://spssi.onlinelibrary.wiley.com/doi/abs /10.1111/j.1540-4560.1992.tb01949.x

Seo, M. (2019). Amplifying Panic and Facilitating Prevention: Multifaceted Effects of Traditional and Social Media Use During the 2015 MERS Crisis in South Korea. SAGE Publication, 1-20. Retrieved from https://doi.org/10.1177/1077699019857693

Sokolov, M. (2020, March 3). The pandemic infodemic: how social media helps (and hurts) during the coronavirus outbreak. The Drum Ink. Retrieved from https://www.thedrum.com/opinion/2020/03/03/the-pandemic-infodemic-how-socialmedia-helps-and-hurts-during-the-coronavirus

Slovic, P. (1987). Perception of Risk. Science, vol. 236, 280-285. Retrieved from $10.1126 /$ science. 3563507

Slovic, et al. (2004). Risk as Analysis and Risk as Feelings: Some Thoughts about Affect, Reason, Risk, and Rationality. Risk Analysis Journal 24(2), 311-322. Society for Risk Analysis: PubMed. Retrieved from https://doi.org/10.1111/j.0272-4332.2004.00433.x

Statista Research Department. (2010). COVID-19 confirmed cases Malaysia 2020 by state. Retrieved from https://www.statista.com/statistics/1107426/malaysia-covid-19confirmed-cases-by-state/

Thomas, Z. (2020, February 13). WHO says fake coronavirus claims causing 'infodemic'?. BBC News. Retrieved from https://www.bbc.com/news/technology-51497800 